Article

\title{
Anne's Secret: Teaching Children to Protect Themselves from Child Sexual Abuse Using Animated Cartoons
}

\author{
Pilar Rueda $^{1, *(\mathbb{D}}$, Marta Ferragut ${ }^{1}\left(\mathbb{C}\right.$, M. Victoria Cerezo $^{1}\left(\mathbb{D}\right.$, Isabel Calvo $^{2}$ and Margarita Ortiz-Tallo ${ }^{2}$ \\ 1 Faculty of Psychology, University of Malaga, 29071 Malaga, Spain; mferragut@uma.es (M.F.); \\ mvcerezo@uma.es (M.V.C.) \\ 2 Con.ciencia Association, 29017 Malaga, Spain; doctora@isabelcalvo.es (I.C.); mortiztallo@uma.es (M.O.-T.) \\ * Correspondence: pilarrueda@uma.es
}

check for

updates

Citation: Rueda, P.; Ferragut, M.;

Cerezo, M.V.; Calvo, I.; Ortiz-Tallo, M. Anne's Secret: Teaching Children to Protect Themselves from Child Sexual Abuse Using Animated Cartoons. Sexes 2022, 3, 134-140. https://doi.org/10.3390/sexes3010011

Academic Editor: David L. Rowland

Received: 15 November 2021

Accepted: 29 January 2022

Published: 9 February 2022

Publisher's Note: MDPI stays neutral with regard to jurisdictional claims in published maps and institutional affiliations.

Copyright: (C) 2022 by the authors. Licensee MDPI, Basel, Switzerland. This article is an open access article distributed under the terms and conditions of the Creative Commons Attribution (CC BY) license (https:/ / creativecommons.org/licenses/by/ $4.0 /)$.

\begin{abstract}
This paper presents an innovative methodology for the prevention of child sexual abuse (CSA): animated cartoons. CSA is a political, social, educational, and psychological problem that affects many children according to the World Health Organization (WHO). That is why prevention becomes an essential tool for the protection of children. Children are increasingly accustomed to the use of digital media, both for learning and for entertainment. In response to this evolution on how information is transmitted and according to the tradition that cartoons have always had of transmitting values such as friendship, ecology, or solidarity, a 15-minute long video was developed. This video is an animated cartoon, presenting a story. It is composed of music, six friends, and three fantasy characters, and it was designed for children to learn resources to ask for help in case they are suffering CSA. The video is accompanied by a workbook through which both children and adults reinforce what they have learned in the cartoons and learn additional keys for their protection. Data from the first pilot studies carried out to test the effectiveness of this methodology are also presented, with promising results.
\end{abstract}

Keywords: child sexual abuse; children; prevention; cartoons; education; school

\section{Introduction}

In recent years, studies in the field of education and the neurosciences show that the best way to promote learning is by activating curiosity, through manipulation, play, and investigation [1,2]. Although this type of learning has proven to be effective at different developmental stages, it becomes especially important during childhood. Manipulation, curiosity, and play involve the activation of brain areas that are not only involved in information processing, reflective thinking, and the understanding and storage of information but also areas related to emotions. So, there is now a widespread consensus that the best way to teach is to awaken students' curiosity [3,4]. This new knowledge and advances in the field of pedagogy and teaching entail the responsibility for educators to generate methodologies that, through these principles, facilitate young children's learning [2,5].

On this basis emerges the idea of teaching children using cartoons. There are many cartoon series available today that teach a second language, numbers, knowledge about nature or history, or values such as solidarity or respect [6]. In this line, this paper proposes to teach young children how to identify and protect themselves from child sexual abuse (CSA) through a short animated cartoon (and a workbook) with which children can easily identify through images and fantasy. This way of transmitting information also makes it more accessible for adults because CSA is still a topic that tends to generate fear and is usually difficult for parents to address. However, the size of this global health problem indicates the need to make society aware of and involved in prevention. The World Health Organization (WHO) defines CSA as the involvement of a child in sexual activity that he or she does not fully comprehend, is unable to give informed consent to, or for which the child 
is not developmentally prepared and cannot give consent, or that violates the laws or social taboos of society. CSA is evidenced by this activity "between a child and an adult or another child who by age or development is in a relationship of responsibility, trust, or power, the activity being intended to gratify or satisfy the needs of the other person" [7] (p. 75).

International prevalence studies show alarming figures worldwide. Barth et al. [8], analyzing studies from 24 countries, found a prevalence range between 0 and $69 \%$ in women and up to $47 \%$ in men. The WHO reports that one out of five girls are victims of CSA and one out of seven boys [9]. A recent meta-analysis, conducted by Pan et al. [10], yielded CSA figures of around $24 \%$ in women. It should not be forgotten that the shame and fear surrounding CSA means that many of the cases never become known [11]. The prevalence studies suffer from a heterogeneous methodology that does not allow comparisons to be made and fail to clearly define what is considered CSA, and the figures found will depend dramatically on this definition. Thus, for example, recent retrospective studies carried out in Spain and Mexico with large samples of women show percentages that reach 53.1\% [12] and $65.8 \%$ [13] of women who have been rubbed with or against their genitals during childhood or adolescence (being the most common type of abuse reported). Ferragut et al. [14] determined the prevalence of a representative Spanish sample by asking adults retrospectively. They explored 10 different kinds of events considered CSA. The prevalence for each type of CSA experience revealed that the most common experience was being shown pornographic material $(18.5 \%)$, while the one with the lowest prevalence was being forced to perform a sexual act involving penetration (2.8\%). These authors highlighted that, although $2.8 \%$ may not seem to be a large amount, this means that approximately one in 35 of the Spanish adults surveyed had suffered penetration during their childhood, without finding gender differences in this regard. It is crucial to investigate the prevalence of this maltreatment among men, who seem to be reluctant to disclose, even in adulthood [15].

In previous studies in Spanish populations, it was reported that the most common age to have suffered any CSA contact for the first time was 6 years $[12,16]$. These data agree with other academics who highlight that the age period of greatest risk is between 6 and 11 years [17-19].

Many events can affect children's healthy development, ranging from their own or other family members' physical or mental illnesses to socio-economic situations, including traumatic life events, and CSA falls within this category. Suffering CSA can affect not only the child's physical and emotional health but also their subsequent development [20-22]. Medium/long-term consequences have been documented, ranging from physical problems, such as unexplained physical symptoms, headaches, or insomnia, anxious-depressive symptoms, and social isolation to the development of serious disorders such as borderline personality disorder or attachment disorders [23-25]. That is why social awareness of this problem, and the development of educational and prevention programs are essential [24,26].

\section{Anne's Secret: Video Story}

Anne's Secret was born as an innovative methodology to teach children to seek help in a situation in which they are victims of sexual abuse. From the idea of using cartoons for this purpose, a focus group was created with 10 children between 5 and 12 years old with whom researchers discussed what elements cartoons should have to be attractive to them. Several keys emerged from this focus group: the video story should be about a group of friends, there should be animals, it should be about something that must be discovered, found out, or guessed, and there should be a hiding place or a secret shelter in a tree.

These ideas were used to guide the creation of the script. CSA is characterized by several points that usually occur almost identically in all cases: bribing the child, giving gifts in exchange for their silence and for participating in the activity; secrecy: the child is convinced in various ways that they must keep the secret, either because it is something "very special" or because it is forbidden and, if someone finds out, they could be punished [27]; and finally, threats are used. As abuse produces a situation of inequality between the child and the abuser because the abuser is older and has some kind of authority 
or power, the threat of terrible consequences if the child tells about the abuse is usually present as well.

Secrecy and threat have been used as central themes of the plot, thus becoming the objective of the drawings to teach children to identify something they do not like or that makes them feel uncomfortable and to distinguish between a positive secret that can be kept for a while and secrets that harm them. Two "magical" characters were designed to serve as narrators of the story, to give coherence, and help the children to follow it. The figure of a tree, the "mother tree", and an owl were selected as symbolic representatives of knowledge and intuition. The figure of a dog acts as an element that connects the children's experience with this knowledge and intuition.

The story begins with a gang of friends, three boys and three girls of undetermined age, around eight to nine years old, who are playing in a park. They are Caucasian, Asiatic, Latin American, and African. One of the girls, Anne, is apart from the others and appears downcast. The group of friends notices this and asks her what the matter is with her, but she does not want to tell. Then, dialogues emerge, both between the children and between the characters that represent knowledge and intuition. The friends manage to convince Anne to tell them what the matter is with her. At that time, through abstract images and a vocabulary typical of children of that age (for example, "at first, he told me he wanted to play, but then I did not like the game" and "he told me that if I told anyone, everyone was going to be angry with me"), the audience can see what has happened to Anne. Then, her friends assist her to seek help by telling a trusted adult. The cartoon encourages the children to talk to five trustworthy adults.

The action takes place using a child's vocabulary that at no time produces fear in the children. Color contrast and drawing style are also used: while the children are together, talking and playing, the colors are clear. The moment Anne tells them how bad she feels when she "has to play" that "game", the colors become dark, and the strokes of the drawing change. At the end of the short cartoon, which lasts $15 \mathrm{~min}$, the owl sings a song. The lyrics and music of this song, written and composed for this purpose and supervised by the psychological team of Asociación Con.ciencia [28,29], aims to facilitate children's integration of learning how to recognize and identify their bodily sensation when something bothers them, to distinguish between a secret that can be kept and one that cannot, and to report to a trustworthy adult when something like this happens to them. The song has a part that is sung in rap style that encourages children's learning and allows them to rap/sing the chorus. For some authors, the term rap can be an acronym for rhythm and poetry; recite a poem; revolution, attitude, and poetry; or respect and peace. All of them are objectives of the song [30].

\section{Anne's Secret: The Workbook}

As complementary material to the video, a workbook was created, which will strengthen the learnings from the video through exercises that the children will do, both in groups and individually [31]. This workbook is designed in a playful style, and the exercises can be completed via writing and drawing. One by one, the tasks review all the basic elements that adults and children should know to protect others and themselves from CSA, ranging from the recognition of sadness and intuition, the differentiation between a game and something that is not a game, and seeking help, including other basic elements. For each point addressed, an explanatory key is given to adults. Thus, for example, when talking about sadness, adults are guided on how to talk to children to help them express and relieve their sadness. Specifically, the exercises are structured on the following themes: (1) play, (2) sadness, (3) intuition, (4) good and bad Secrets, (5) help from others, (6) the abuse or violence of others, (7) the five trusted people, (8) the secret word, (9) music, and (10) the gang.

Figure 1 represents an example of Exercise 2 on sadness, which shows how a photogram of the drawings always appears, and then questions are asked for the children to work on, and, on the right, a box appears in which indications are given for adults. 


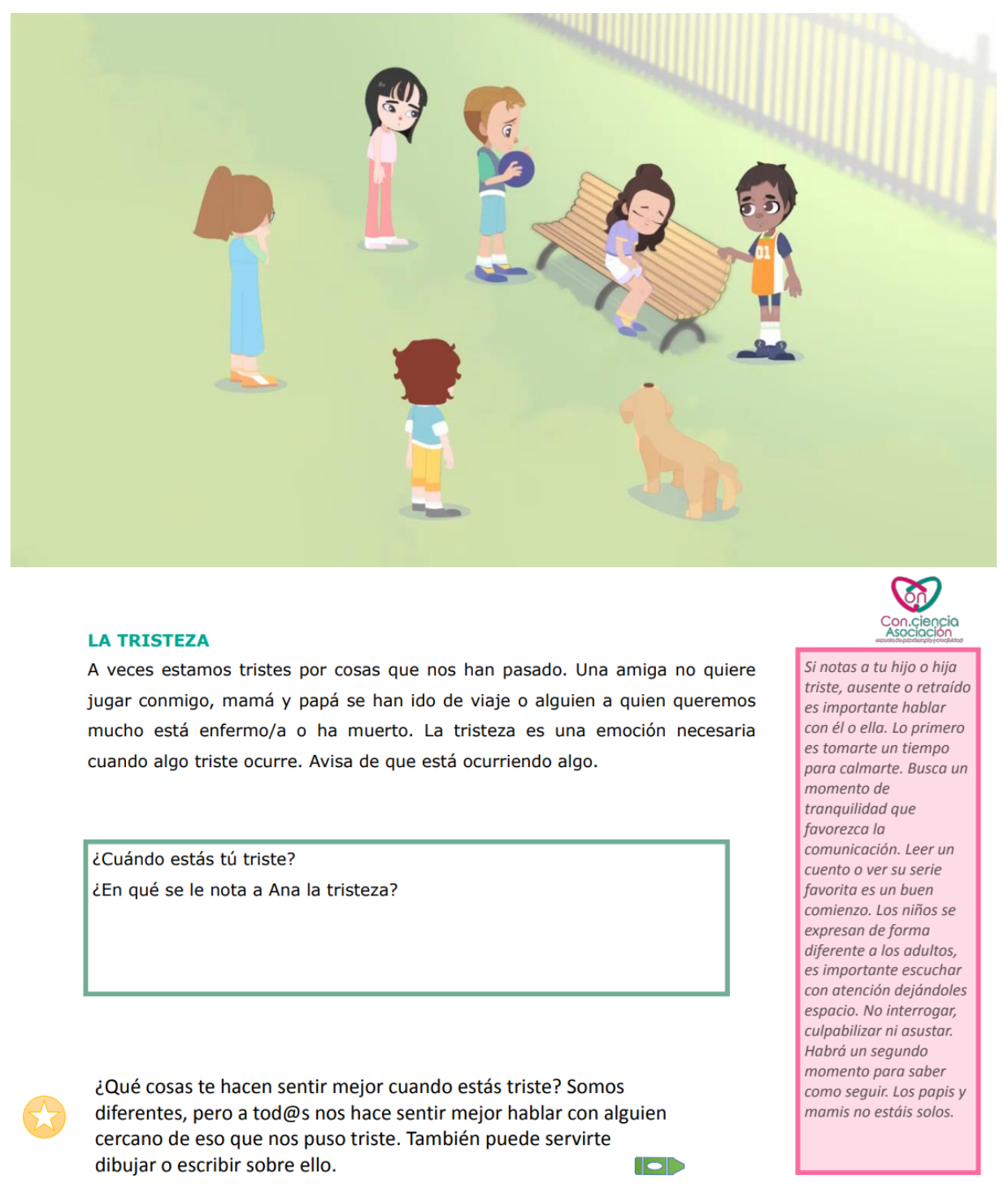

Figure 1. Example of an activity from the workbook about sadness.

\section{Pilot Experiences Using Cartoons to Prevent CSA}

To date, the cartoons have been used four times in a teaching context, obtaining promising results. The psychologists in charge present themselves, explain that everyone is going to watch cartoons to learn "some important things" and do some group dynamics with the children to facilitate communication and a relaxed learning environment. In these dynamics, questions such as "Do you know what intuition is?", "How do you realize that a friend is sad?", and "Who takes care of you when you feel sad?" are introduced. Then, the participants start to view the cartoon.

It is essential for the children to display active observation while they watch the video in order to detect possible situations of identification with the characters, confusion, or distress.

Once the short cartoon is over, the children share what has caught their attention, what they liked, what they would do if what happened to Anne happened to a friend, etc. After this sharing, they work on the workbook with the support of teachers and the psychologists. In addition to strengthening the learning carried out, this activity allows educators and parents to have information about, for example, who are the children's trusted people because they can take the workbook home. Special emphasis is placed on the need to have a list of at least five adults that they can turn to. These people should belong to different areas of the child's life: family and school. Likewise, the identification of sadness and what 
constitutes an abusive situation (always in a language that children understand and that does not frighten them) are addressed.

The cartoon has also been presented to teachers in eight schools to train these professionals so that they can carry out the dynamics with the children during their classes.

A pilot evaluation of the effectiveness of this teaching method based on cartoons and the workbook has been carried out through an author-elaborated instrument [32]. This instrument, composed of four questions with a Likert-type response format, addresses the fundamental points treated in the cartoons, both before and after their viewing. For instance, one of the questions is "Do you know the difference between a bad secret and a good secret?". The results obtained from a group of 36 children aged between 8 and 10 years ( 15 girls) showed that the goal of the learning was achieved through the cartoons and the workbook: children knew what intuition was and how to recognize it in their body, they could differentiate between a "good" secret and a "bad" secret, and they were clear about which trusted people they could turn to when they feel uncomfortable or sad. As a future line of research, we contemplate analyzing more complete data on the effectiveness of the program, including other instruments, expanding the sample, and carrying out a third evaluation after the viewing, to confirm that the learnings are maintained and that the children would know how to put them into practice if they needed them. Informed consent to work with children and to collect their responses was obtained from their caregivers before the day of the activity.

\section{Working with Adults}

In the prevention and eradication of CSA, the active role of adults is fundamental because under no circumstances can prevention be delegated exclusively to the children. That is why work through psycho-education and awareness is essential [33]. The proposed program, whose core is the short cartoon, includes an explanatory talk with parents and educators before the children view the cartoon. This talk is structured so that, without alarming them, adults become aware of the high prevalence of CSA and the need for everyone to be involved in its prevention. Parents and educators are allowed to express their doubts and fears about this issue. They are also instructed not only about how to detect warning signs but also how to act if a child tells them that they have been abused. It is useless for children to seek help if there are no adults prepared to listen to them [34]. Hence the chorus of the song, "You are not alone, I am listening to you".

\section{Conclusions}

In a world that depends increasingly on images for the transmission of information, new teaching-learning methodologies are necessary to facilitate not only the acquisition but also the integration of new knowledge [2]. With CSA being such a widespread problem at all socio-cultural levels and with consequences not only for the victim but also for the family $[20,21]$, it is necessary to involve all of society in its eradication. For this purpose, including prevention programs within educational policies is necessary, as well as the involvement of all strata of society $[12,20,26,27]$. In addition to academic knowledge proper, the educational curriculum must include socio-emotional education that promotes healthy development from early childhood [3,5]. The use of cartoons is proposed as an effective and desirable strategy from which children can approach a delicate and complex subject using their imagination and, in a language, (through image, color, and sound) that is familiar and easy to integrate [6].

Author Contributions: Conceptualization: P.R. and M.O.-T.; writing—original draft preparation: P.R. and M.O.-T.; methodology: P.R., M.F., M.V.C., I.C., and M.O.-T.; writing-review and editing: P.R., M.F., M.V.C., I.C., and M.O.-T. All authors have read and agreed to the published version of the manuscript.

Funding: This project has been selected and financially supported by the call "Soles de Málaga 2021" of the Fundación El Pimpi (Malaga, Spain). 
Institutional Review Board Statement: This study was conducted according to the guidelines of the Declaration of Helsinki and approved by the Ethics Committee of the University of Malaga (protocol code 18-2020-H approved 6 May 2020).

Informed Consent Statement: Informed consent was obtained from all subjects involved in the study.

Acknowledgments: The authors would like to express their gratitude to all of the team members that contributed to the development of the cartoons.

Conflicts of Interest: The authors declare no conflict of interest.

\section{References}

1. Basargekar, A.; Lilllard, A. Math achievement outcomes associated with Montessori education. Early Child Dev. Care 2021, 191, 1207-1218. [CrossRef]

2. Lillard, A. Montessori as an alternative early childhood education. Early Child Dev. Care 2021, 191, 196-1206. [CrossRef]

3. Matthews, B. Engaging Education, Developing Emotional Literacy, Equity and Co-Education; Open University Press: Columbus, OH, USA, 2006.

4. Tew, M. Shaping a CLASI School; Raising Achievement Update; Optimus: London, UK, 2007; Volume 42, pp. 4-5.

5. Matusov, E. Progressive education is the opium for the educators. Integr. Psychol. Behav. Sci. 2021. [CrossRef] [PubMed]

6. Bahrani, T.; Soltani, R. The pedagogical values of cartoons. Res. Humanit. Soc. Sci. 2011, 1, 19-23.

7. World Health Organization (WHO). Guidelines for Medico-Legal Care for Victims of Sexual Violence; World Health Organization: Geneva, Switzerland, 2003. Available online: https://apps.who.int/iris/bitstream/handle/10665/42788/924154628X.pdf? sequence $=1$ (accessed on 7 February 2022).

8. Barth, J.; Bermetz, L.; Heim, E.; Trelle, S.; Tonia, T. The current prevalence of child sexual abuse worldwide: A systematic review and meta-analysis. Intern. J. Public Health 2013, 58, 469-483. [CrossRef]

9. World Health Organization (WHO). Child Maltreatment; World Health Organization: Geneva, Switzerlandm, 2016. Available online: http:/ / www.who.int/mediacentre/factsheets/fs150/es/ (accessed on 7 February 2022).

10. Pan, Y.; Lin, X.; Liu, J.; Zhang, S. Prevalence of childhood sexual abuse among women using the Childhood Trauma Questionnaire: A worldwide meta-analysis. Trauma Violence Abuse 2021, 22, 1181-1191. [CrossRef]

11. Finkelhor, D.; Ormrod, R.; Turner, H.A.; Hamby, S.L. Child and youth victimization known to school, police, and medical officials in a national sample of children and youth. Juv. Justice Bull. Off. Juv. Justice Delinq. Prev. U. S. Dep. Justice 2012, 235394, 1-8. Available online: https:/ / ojjdp.ojp.gov/sites/g/files/xyckuh176/files/pubs/235394.pdf (accessed on 7 February 2022).

12. Ferragut, M.; Ortiz-Tallo, M.; Blanca, M.J. Spanish women's experiences of child sexual abuse. Psicothema 2021, 33, 236-243. [CrossRef]

13. Rueda, P.; Ferragut, M.; Cerezo, M.V.; Ortiz-Tallo, M. Experiences of CSA in Mexican women: Age, type of experience, perpetrator, and disclosure. Int. J. Environ. Res. Public Health 2021, 18, 6931. [CrossRef]

14. Ferragut, M.; Ortiz-Tallo, M.; Blanca, M.J. Prevalence of child sexual abuse in Spain: A representative sample study. J. Interpers. Violence 2021, 36, 08862605211042804. [CrossRef]

15. Okur, P.; Van der Knaap, L.M.; Bogaerts, S. A Quantitative Study on Gender Differences in Disclosing Child Sexual Abuse and Reasons for Nondisclosure. J. Interpers. Violence 2020, 35, 5255-5275. [CrossRef]

16. Ferragut, M.; Ortiz-Tallo, M.; Blanca, M.J. Victims and Perpetrators of Child Sexual Abuse: Abusive Contact and Penetration Experiences. Int. J. Environ. Res. Public Health 2021, 18, 9593. [CrossRef]

17. Al-Mahroos, F.; Al-Amer, E. Reported child sexual abuse in Bahrain: 2000-2009. Ann. Saudi Med. 2011, 31, 376-382. [CrossRef] [PubMed]

18. Cortés, R.; Cantón, J.; Cantón-Cortés, D. Characteristics of sexual abuse of minors and its consequences on victims' mental health. Gac. Sanit. 2011, 25, 157-165. [CrossRef]

19. Guziak, M.A. Child sexual abuse among Polish adult population: Prevalence and abuse characteristics. PsyArXiv 2020, 31, 1-21. [CrossRef]

20. Kiser, L.A.; Smith-Stover, C.; Navalta, C.; Dorado, J.; Vogel, J.F.; Abdul-Adil, J.K.; Soeun, K.; Leei, R.C.; Vivrette, R.; Ernestine, C. Effects of the child-perpetrator relationship on the mental health outcomes of child abuse: It's not all relative. Child Abus. Negl. 2014, 38, 1083-1093. [CrossRef] [PubMed]

21. Ortiz-Tallo, M.; Calvo, I. Child sexual abuse: Listening to the victims. Arch. Community Med. Public Health 2020, 6, 135-137. [CrossRef]

22. Quintero-Hernández, Y.A. Relatos dominantes opresivos de mujeres con historias de abuso sexual infantil [Dominant oppressive accounts of women with stories of child sexual abuse]. Controv. Y Concurr. Latinoam. 2019, 11, 199-213. Available online: https:/ / ojs.sociologia-alas.org/index.php/CyC/article/view/99 (accessed on 7 February 2022).

23. Fillipas, H.H.; Ullman, S.E. Child sexual abuse, coping responses, self-blame, post-traumatic stress disorder and adult sexual revictimization. J. Interpers. Violence 2006, 21, 652-672. [CrossRef]

24. Goldsmith, R.E.; Freyd, J.J.; DePrince, A.P. Betrayal trauma: Associations with psychological and physical symptoms in young adults. J. Interpers. Violence 2012, 27, 547-567. [CrossRef] 
25. Felitti, V.; Anda, R. The relationship of adverse childhood experiences to adult medical disease, psychiatric disorders, and sexual behavior: Implications for healthcare. In The Impact of Early Life Trauma on Heath and Disease: The Hidden Epidemic; Lanius, R., Vermetten, E., Pain, C., Eds.; Cambridge University Press: Cambridge, UK, 2010; pp. 77-87. [CrossRef]

26. Ferragut, M.; Rueda, P.; Cerezo, M.V.; Ortiz-Tallo, M. What do we know about child sexual abuse? Myths and truths in Spain. J. Interpers. Violence 2022, 37, NP757-NP775. [CrossRef] [PubMed]

27. Rueda, P.; Ferragut, M.; Cerezo, M.V.; Ortiz-Tallo, M. Creando conciencia sobre el abuso sexual infantil: Desmontando mitos y dotando de recursos [Raising awareness about child sexual abuse: Debunking myths and providing resources]. In La Convención Sobre Los Derechos Del Niño a Debate Treinta Años Después; Jiménez, A., Ghannami, O., Ordaz, G., Heredia, K.M., Brigitte, J., Niño, N., Lara, L., Santos, A., de Alvarenga, A.R., García, D., et al., Eds.; CIPI Ediciones: Huelva, Spain, 2019 ; pp. 486-501. ISBN 978-84-09-13979-8.

28. Lasso de la Vega, A.; Lasso, G. Song lyric "No estás sola", donTeclas: Málaga, Spain, 2020.

29. Bermúdez, D. Song music "No estás sola", donTeclas: Málaga, Spain, 2020.

30. Más Lengua y Literatura. Rap. Más Lengua y Literatura blog. 2019. Available online: https://masliteraturablog.wordpress.com/ 2019/09/18/rap/ (accessed on 7 February 2022).

31. Calvo, I.; Ortiz-Tallo, M.; Ferragut, M.; Cerezo, M.V.; Rueda, P. El Secreto de Ana: Guía Para Familias Y Profesorado [Anne's Secret: Workbook for Families and Teachers]; Asociacion Con.ciencia: Málaga, Spain, 2021.

32. Ferragut, M.; Cerezo, M.V.; Rueda, P. Eficacia de los talleres de prevención del abuso sexual. In Conductas de Riesgo En Adolescentes Desde Una Perspectiva Multidisciplinar [Risk Behaviors in Adolescents from a Multidisciplinary Perspective]; Pérez-Fuentes, M.C., Molero, M.M., Martos, A., Barragán, A.B., Simón, M.M., Tortosa, B.M., Del Pino, R.M., Gázquez, J.J., Eds.; ASUNIVEP: Almería, Spain, 2020; pp. 73-78. ISBN 978-84-09-23754-8.

33. Save the Children. Abuso Sexual Infantil: Manual de Formación Para Profesionales [Child Sexual Abuse: Training Manual for Professionals]; Save the Chidlren: Madrid, Spain, 2001; Available online: https://www.savethechildren.es/sites/default/files/imce/docs/ manual_abuso_sexual.pdf (accessed on 7 February 2022).

34. Save the Children. Guía de Recursos Para La Prevención Y Atención Del Abuso Y La Explotación Sexual Infantil [Resource Guide for the Prevention of and Response to Child Sexual Abuse and Exploitation]; Save the Children: Madrid, Spain, 2012; Available online: http: //ibdigital.uib.es/greenstone/sites/localsite/collect/cd2/index/assoc/stc0083.dir/stc0083.pdf (accessed on 7 February 2022). 